\section{2-Year Follow-Up of Regenerative Endodontic Treatment of Immature Permanent Upper Incisors with Acute Abscess}

Claudio Maniglia-Ferreira ${ }^{1} \mathbb{D}$, Eduardo Diogo Gurgel Filho ${ }^{1} \mathbb{D}$, Fabio de Almeida Gomes ${ }^{1} \mathbb{D}$, Sthefanny Amaral Reis ${ }^{1} \mathbb{B}$, Fernanda Geraldo Pappen ${ }^{2}$ (D)

\author{
'Department of Endodontics, School \\ of Dentistry, UNIFOR - Universidade \\ de Fortaleza, Fortaleza, CE, Brazil \\ ${ }^{2}$ Department of Semiology and \\ Clinics, Diagnostic Center for \\ Oral Diseases, School of Dentistry, \\ UFPEL - Universidade Federal \\ de Pelotas, Pelotas, RS, Brazil
}

Correspondence: Claudio ManigliaFerreira, Rua Bento Albuquerque, 685, ap. 1102, 60192-060 Fortaleza, CE, Brasil. Tel: +55-85-988127517. e-mail: maniglia@unifor.br

Key Words: dental trauma, immature permanent tooth, acute apical abscess, regenerative endodontics.

\section{Introduction}

Treatment of immature permanent teeth with pulp necrosis and apical pathosis constitutes a challenge for endodontists $(1,2)$. Necrotic pulp and intracanal infection are commonly encountered in cases of trauma to the anterior teeth or untreated carious lesions (3). Such conditions are also challenging due to the dentinal walls being very thin, increasing the risk of root fractures (4).

Such cases have historically been managed by apexification procedures using calcium hydroxide (5). This treatment requires long-term placement of calcium hydroxide within the root canal to induce formation of an apical hard-tissue barrier (5).

The periapical tissues around immature teeth are rich in blood supply and contain stem cells that have relative potential to regenerate in response to tissue injury (6). Accordingly, RET has more advantages compared with apexification as it induces root end development and reinforcement (7). However, apical repair will not take place in the presence of inflamed and infected tissues $(7,8)$.

A variety of decontamination protocols for RET have been reported. Most use sodium hypochlorite as irrigant solution and triple (metronidazole, ciprofloxacin, and minocycline) (TAP) $(7,9)$ or double (metronidazole/ ciprofloxacin) (DAP) $(10,11)$ antibiotic paste as intracanal medicament. Both substances have antimicrobial activity against endodontic pathogens (10-13), which allows repair of apical tissues, cellular induction and reestablishment of root formation (10).

The objective of this case report was to describe a combination of different protocols used in regenerative endodontic treatment (RET) with a 12-year follow up specifically, $2.5 \%$ sodium hypochlorite as an irrigating agent with calcium hydroxide in association with $2 \%$ chlorhexidine gel (CHCXP) and double antibiotic paste (DAP) as intracanal medicaments between sessions - in a 7-year-old child who presented acute apical abscess in the immature upper central incisors after dental trauma.

\section{Case Report}

A 7-year-old girl was brought by her mother in August 2007 to the School of Dentistry of the University of Fortaleza, located in Fortaleza, CE, Brazil, because of pain and swelling in the mucosal area of the permanent upper central incisors 30 days after a bicycle accident. According to information provided by the mother, there 
was a slight intrusion of both teeth, and the left upper central incisor had suffered a dentine enamel fracture without pulp involvement and was restored within $24 \mathrm{~h}$ of the injury. Clinical examination at the initial visit revealed permanent upper central incisors with pulp necrosis and acute apical abscess unresponsive to pulp tests (cold stimuli) and swelling associated with tenderness to percussion and palpation. No coronary cracks and/or isolated periodontal probing defects were identified. Periapical radiographs reveled immature teeth showing thin root dentinal walls and wide-open apex (Fig. 1A). The treatment of choice was RET and its potential outcomes were carefully explained to the patient and her mother.

$3 \%$ Mepivacaine was used as a local anesthetic without the use of vasoconstrictors (Mepisv; DFL, Rio de Janeiro, $\mathrm{RJ}, \mathrm{Brazil}$ ) and the teeth were isolated with a rubber dam. Access cavities were prepared using a diamond bur (KG Sorensen, Barueri, SP, Brazil) and a high-speed handpiece under cooling conditions with copious sterile saline solution. This initial protocol was followed in all clinical sessions. After coronary access, purulent secretion was noted in both teeth.

The root canals were slowly and carefully prepared with hand files (\#140; Dentsply Maillefer, Ballaigues, Switzerland) to the radiographic working length $(1 \mathrm{~mm}$ short of the root apex) to avoid dentin wear. 2.5\% sodium hypochlorite solution (Biodinâmica; Ibiporã, PR, Brazil) and saline solution were used as endodontic irrigants. Root canals were rinsed with $5 \mathrm{~mL}$ of $17 \%$ EDTA, which was kept inside the root canals for $4 \mathrm{~min}$, to clean dentinal walls (9). The final irrigation was carried out with $20 \mathrm{~mL}$ of saline solution. The root canals were dried with sterile paper points and after that $2 \%$ chlorhexidine gel was placed into the root canal to working length and left inside for 7 days (Fig. 1B). Sterile cotton pellets were placed within the pulp chambers and the access cavities were provisionally restored with Vitremer (Resin Modified Glass lonomer, 3M Dental Products, Irvine, CA, USA).

At the second visit, clinical normality was checked and there were no signs and/or symptoms of infection. The teeth were accessed and each root canal was copiously irrigated with $20 \mathrm{~mL}$ saline solution. The irrigation and decontamination protocols used at the first visit were repeated. Thus, the root canals were dried with sterile paper points and the right and left permanent upper central incisors were filled with DAP [a mixture of metronidazole (Flagyl 400, Sanofi-Aventis Farmacêutica Ltda, São Paulo, Brazil) and ciprofloxacin (Cipro 500, Bayer Schering Pharma AG, Leverkusen, Germany) (1:1 ratio)] and calcium hydroxide paste [a creamy calcium hydroxide preparation (Biodinamica) and 2\% chlorhexidine gel (CHCXP) (Endogel; Itapetininga, São Paulo, Brazil) (1:1 ratio)], respectively.
Zinc oxide was mixed to both pastes (1:4 ratio) to obtain radiopacity (11). The access cavities were once again provisionally sealed with Vitremer (Fig. 1C).

At the third visit, which took place after 21 days, the pastes were removed and the periapical areas were stimulated with a \#80 K-file to encourage clot formation within the pulp cavities. A white MTA (Angelus, Londrina, PR, Brazil) cervical plug was placed below the cementoenamel junction. Vitremer was used for definitive restorations.

The patient remained asymptomatic at 1 (Fig. 1D), 5 (Fig. $1 \mathrm{E}$ to $1 \mathrm{H}$ ) and 12 years (Fig. $1 \mathrm{l}$ to $1 \mathrm{~K}$ ) of clinical and radiographic follow-ups (Fig. 1D to 1K). No swelling, fistula, or tenderness to percussion and/or palpation were noted, thus confirming treatment success. CBCT scans revealed progression of root development and apical closure. However, at 5 years of follow-up, CBCT revealed a possible defect in root formation at the right central incisor. At 12 years of follow-up, there was clear evidence of tissue invagination. In addition, increased root canal calcification was observed in both teeth regardless of the intracanal medication used. (Fig. 1K).

\section{Discussion}

The main objective of RET in cases of necrotic pulp is to eliminate infection from within the root canal system and end the inflammatory process in the apical region through biologically compatible procedures that can allow or induce repair of periodontal tissues and of the dentin-pulp complex $(1,2)$. Persistent infection is a major negative factor impacting the histologic regeneration of pulpal tissues after RET (6).

Cleaning and disinfection of the root canal system in immature teeth have been the subject of many studies (14). Over the years, many changes to practice and protocols have been proposed and there have been different combinations of irrigating substances and intracanal medicaments in an attempt to find the best way of promoting an environment conducive to root formation and successful clinical outcomes $(1,15)$.

Because immature dentinal walls cannot be worn down for canal shaping and mechanical (instrument-based) removal of organic debris or infection (8), special attention must be given to irrigation and intracanal medication (14). Several studies have shown that the best irrigating solution is sodium hypochlorite $(2,15)$. In such cases, the canals were gently irrigated with $2.5 \%$ sodium hypochlorite to remove necrotic and infected tissues (15). The use of EDTA is essential to achieve an adequate cleaning of dentinal walls. In addition, it contains properties associated with cell adhesion, migration and differentiation of stem cells towards dentin (9).

Due the patient presented with acute apical abscess 
and purulent secretion at the first visit, we decided to use $2 \%$ chlorhexidine gel as an intracanal medication for
7 days before starting the use of intracanal medication with DAP and CHCXP pastes. Although chlorhexidine may
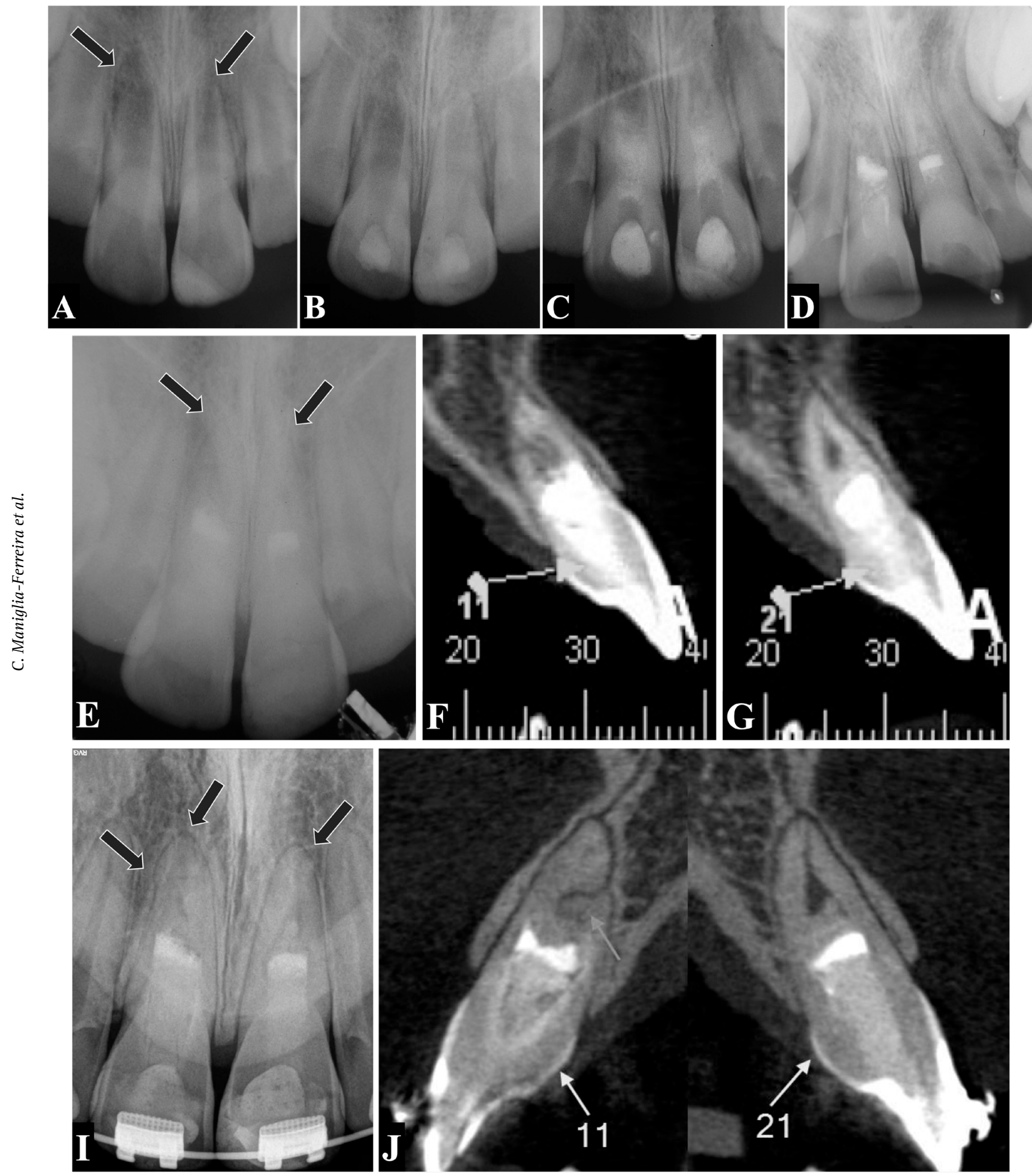

Figure 1. Baseline periapical radiograph showing immature teeth (A); upper central incisors filled with 2\% chlorhexidine gel (B); permanent right and left upper central incisors filled with DAP and CHCXP, respectively (C). Periapical radiograph at 1 year of follow-up (D). At 5 years of follow-up - periapical radiograph (E) and CBCT scans (F and G). It is possible to note complete root formation and no teeth discoloration. At 12 years of follow-up it is possible to note the normality of the periapical and periodontal tissues and the presence of periodontal ligament space and absence of resorption areas (I and J). CBCT scans (right upper central incisor) obtained at 5 and 12 years of follow-up shows evidence of a root contour defect (F) followed by images consistent with tissue invagination and increased intracanal calcification (J). 
compromise the growth of stem cells in the apical papilla (16), $2 \%$ chlorhexidine gel is effective against pathogens that cause apical periodontitis, thereby reducing the remaining infection and allowing a reversal of acute signs and symptoms (17).

Most RET studies consist of case reports that use passive decontamination by TAP, DAP or calcium hydroxide paste as intracanal medication (7). Calcium hydroxide pastes help decontaminate infected root canals (17) and increase proliferation of stem cells in the apical papilla (18). It can be combined with $2 \%$ chlorhexidine to increase the antimicrobial and residual antimicrobial properties and diffusion into dentinal tubules $(12,17)$. This technique using calcium hydroxide combined with $2 \%$ chlorhexidine has been previously used for RET (12). Many studies have demonstrated success in RET using intracanal medication to eliminate endodontic infection in necrotic immature permanent teeth $(1,12,15,19)$, a result that was also achieved in the present case as repair of periapical lesions was observed. With regard to the radiographic examination, periapical lesion repair is a sign that treatment was effective in controlling the infection (8). Furthermore, repair of the apical portion of immature teeth should only begin in organized and uninfected tissue to enable the occurrence of root end development (20).

Stimulation of blood clot (scaffold) formation and stabilization and presence of stem cells and their stimulation by growth factors present in blood clots constitute the basis of the tissue engineering that supports the principles of RET $(1,2,9,14)$. According to ElSheshtawy et al. (21), scaffolds support cell growth and differentiation inside the pulp cavity and are an essential part of any appropriately designed tissue engineering-based strategy for regenerative endodontics $(9,21)$. Despite not being considered a true scaffold, the blood clot into the root canal is the most used among clinicians (22). In this clinical case, the blood clot was successfully used as a scaffold in both teeth submitted to RET. MTA plug was applied onto the blood clot formed to promote scaffold stability and sustain high $\mathrm{pH}$ levels for long periods, thus facilitating the tissue repair and proliferation process (2). This is attributable to factors that allow the stimulation of the epithelial cell rests of Malassez, remnants of Hertwig's epithelial root sheath, which contain a genetic memory of radicular development and are thus able to direct hard-tissue deposition to ensure the continuity of root formation (23). A periapical radiograph and CBCT at 1 year of follow-up revealed progression of root formation and a dentine bridge forming at the middle third of the root canals.

There are no reports in the literature describing invaginations in root formation in cases of RET, as revealed by CBCT images at 5 and 12 years of follow up.
This change may have been stimulated by the presence of CXCAP in contact with periodontal tissues and/or physical compression or stretching of Hertwig's epithelial root sheath cells promoted by dental trauma that probably compromised the repair. This may also have altered the direction of hard-tissue deposition during root formation in the right central incisor, as demonstrated by $\mathrm{CBCT}$ evidence of tissue invagination towards the interior of the root.

Considering the success rate of RET, retrospective studies demonstrated high success rates survival in teeth after regenerative treatment $(1,2)$. In the current case, minocycline was not used to prevent tooth discoloration (22) and MTA plugs were placed $2 \mathrm{~mm}$ below the dentinoenamel junction.

Both teeth kept responsive to pulp sensibility until 5 years of follow-up. After this period, no positive responses to pulp tests by cold stimuli were obtained, but the periapical tissues always remained healthy and without signs and/ or symptoms. The 12-year follow-up radiographic and tomographic images showed that the pulp calcification process occurred in both teeth. The same was reported by Kahler et al. (24) after 8 years of follow-up of teeth submitted to RET. However, the tomographic image showed that the calcification was more intense in the tooth in which calcium hydroxide paste was used as an intracanal medication. A similar finding was reported by Song et al. (25), but it may have been influenced by the occurrence of invagination.

Thus, the reporting of clinical cases of necrotic immature permanent teeth treated by RET protocols with a followup of over 10 years is recommended to check whether the concepts and procedures in these clinical approaches are providing longevity and clinical success. In this case report, zinc oxide was added to pastes used as intracanal medication, in order to increase radiopacity. However, although the use of zinc oxide is already widely used in endodontics, there are no studies that used the combination $\mathrm{CH}+\mathrm{CX}+\mathrm{ZnO}$ for the regenerative endodontic treatment. Thus, future studies using these intracanal medication protocols (adding zinc oxide) should be carried out in order to analyze the effects on stem cell migration, adhesion and release of root dentin growth factors, which are still unknown.

The present case report clearly shows the importance of promoting an intracanal environment free of infection so that genetic induction and continuity of root formation can take place. RET should be considered as a first treatment option in the treatment of immature teeth with pulp necrosis. The correct thickness and adaptation of cervical MTA plug are essential to maintaining blood clot integrity so as to promote a stable scaffold and the success of RET. The successful outcome of this case is demonstrated by 
the absence of signs or symptoms of inflammation and by radiographic and CBCT evidence of root formation and integrity over 12 years of follow-up. As recommended by Kahler et al. (20), AAE clinical considerations for a regenerative endodontic procedure should be updated to include the potential of root canal calcification after RET.

\section{Resumo}

Este relato de caso discute o tratamento endodôntico de uma menina de 7 anos que sofreu trauma nos incisivos centrais superiores imaturos, após queda de bicicleta. Trinta dias após o acidente, a paciente foi levada pela mãe para avaliação clínica e radiográfica com queixa principal de inchaço e sensibilidade à percussão e palpação. Foram diagnosticados abscessos apicais agudos em ambos os dentes. Foi decidido por realizar o tratamento endodôntico regenerativo. Após acessos coronários, os canais radiculares foram submetidos à protocolos de antissepsia com auxílio de irrigação com hipoclorito de sódio a 2,5\% e EDTA 17\%. Devido à dor e presença de secreções, foi utilizada medicação intracanal com clorexidina gel 2\% por 7 dias. Na segunda sessão, os canais radiculares foram novamente submetidos aos procedimentos de antissepsia e os canais dos incisivos centrais superiores permanentes direito e esquerdo foram preenchidos com pasta antibiótica dupla (Metronidazol / Ciprofloxacina) e pasta de hidróxido de cálcio, respectivamente. Em ambas as pastas foi adicionado o óxido de zinco. Na terceira sessão, após mais 21 dias, as pastas foram removidas e as regiões periapicais foram estimuladas com lima $\mathrm{K} \mathrm{n}^{\circ}$ 80 para incentivar a formação de coágulos sanguíneos no interior das cavidades pulpares. Tampões cervicais de MTA foram adaptados e os dentes restaurados com cimento de ionômero de vidro resinoso. Radiografias e tomografias computadorizadas demonstraram formações radiculares completas. A paciente é acompanhada há 12 anos, com evidências clínicas e radiográficas de sucesso.

\section{Acknowledgements}

The authors deny any conflicts of interest.

\section{References}

1. Diogenes $A$, Ruparel NB. Regenerative endodontic procedures: clinical outcomes. Dent Clin North Am 2017;61:111-125.

2. Kim SG, Malek $M$, Sigurdsson $A$, Lin $L M$, Kahler B. Regenerative endodontics: a comprehensive review. Int Endod J 2018;51:1367-1388.

3. Fouad AF. Microbiological aspects of traumatic injuries. Dent Traumatol 2019;35:324-332.

4. Duggal M, Tong HJ, Al-Ansary M, Twati W, Day PF, Nazzal H. Interventions for the endodontic management of non-vital traumatized immature permanent anterior teeth in children and adolescents: a systematic review of the evidence and guidelines of the european academy of paediatric dentistry. Eur Arch Paediatr Dent 2017; 18:139-151.

5. Chala $S$, Abouqal $R$, Rida $S$. Apexification of immature teeth with calcium hydroxide or mineral trioxide aggregate: systematic review and meta-analysis. Oral Surg Oral Med Oral Pathol Oral Radiol Endod 2011;112:e36-42.

6. Cameron R, Claudia E, Ping W, Erin S, Ruparel NB. Effect of a residual biofilm on release of transforming growth factor $\beta 1$ from dentin. J Endod 2019;45:1119-1125.

7. Lin $L M$, Rosenberg PA. Repair and regeneration in endodontics. Int Endod J 2011;44:889-906.

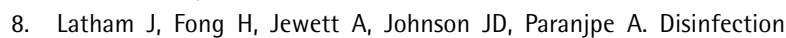
efficacy of current regenerative endodontic protocols in simulated necrotic immature permanent teeth. J Endod 2016;42:1218-1225.

9. Galler KM, Widbiller M, Buchalla W, Eidt A, Hiller KA, Hoffer PC, et al. EDTA conditioning of dentine promotes adhesion, migration and differentiation of dental pulp stem cells. Int Endod J 2016;49:581-590.

10. Zancan RF, Vivan RR, Milanda Lopes MR, Weckwerth PH, de Andrade FB, Ponce JB, et al. Antimicrobial activity and physicochemical properties of antibiotic pastes used in regenerative endodontics. Braz Dent $J$ 2019;30:536-541.

11. Maniglia-Ferreira C, de Almeida Gomes F, Vitoriano MM. Intentional replantation of an avulsed immature permanent incisor: a case report. J Endod 2017;43:1383-1386.

12. Nagata JY, Soares AJ, Souza-Filho FJ, Zaia AA, Ferraz CC, Almeida JF, et al. Microbial evaluation of traumatized teeth treated with triple antibiotic paste or calcium hydroxide with $2 \%$ chlorhexidine gel in pulp revascularization. J Endod 2014;40:778-783.

13. Maniglia-Ferreira C, de Almeida-Gomes F, Pinto MM, de Sousa Barbosa $\mathrm{FT}$, de Farias Filho DM, Albuquerque NL. In vitro evaluation of the antimicrobial effects of different intracanal medications in necrotic immature teeth. Eur Arch Paediatr Dent 2016;17:251-255.

14. Kontakiotis EG, Filippatos CG, Tzanetakis GN, Agrafioti A. Regenerative endodontic therapy: a data analysis of clinical protocols. J Endod 2015;41:146-154.

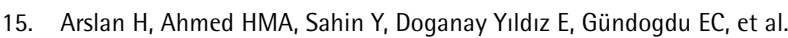
Regenerative endodontic procedures in necrotic mature teeth with periapical radiolucencies: a preliminary randomized clinical study. $J$ Endod 2019;45:863-872.

16. Widbiller M, Althumairy RI, Diogenes A. Direct and indirect effect of chlorhexidine on survival of stem cells from the apical papilla and its neutralization. J Endod 2019;45:156-160.

17. Barbosa-Ribeiro $M$, Arruda-Vasconcelos $R$, de-Jesus-Soares $A$, Zaia $A A$, Ferraz CCR, de Almeida JFA, et al. Effectiveness of calcium hydroxidebased intracanal medication on infectious/inflammatory contents in teeth with post-treatment apical periodontitis. Clin Oral Investig 2019;23:2759-2766.

18. Ruparel NB, Teixeira FB, Ferraz CC, Diogenes A. Direct effect of intracanal medicaments on survival of stem cells of the apical papilla. J Endod 2012;38:1372-1375.

19. Sharma G, Ahmed HM, Zilm PS, Rossi-Fedele G. Antimicrobial properties of calcium hydroxide dressing when used for long-term application: a systematic review. Aust Endod J 2018;44:60-65.

20. Kahler B, Rossi-Fedele G, Chugal N, Lin LM. An evidence-based review of the efficacy of treatment approaches for immature permanent teeth with pulp necrosis. J Endod 2017;43:1052-1057.

21. EISheshtawy AS, Nazzal H, El Shahawy OI, El Baz AA, Ismail SM, Kang J, et al. The effect of platelet-rich plasma as a scaffold in regeneration/ revitalisation endodontics of immature permanent teeth assessed using 2-dimensional radiographs and cone beam computed tomography: a randomised controlled trial. Int Endod J 2020;53:905-921.

22. Nazzal H, Kenny K, Altimimi A, Kang J, Duggal MS. A prospective clinical study of regenerative endodontic treatment of traumatized immature teeth with necrotic pulps using bi-antibiotic paste. Int Endod J 2018;51:e204-e215.

23. Li J, Parada C, Chai Y. Cellular and molecular mechanisms of tooth root development. Development 2017;144:374-384.

24. Kahler B, Kahler SL, Lin LM. Revascularization-associated intracanal calcification: a case report with an 8-year review. J Endod 2018:44:1792-1795.

25. Song $M$, Cao $Y$, Shin SJ, Shon WJ, Chugal N, Kim RH, et al. Revascularization-associated intracanal calcification: assessment of prevalence and contributing factors. J Endod 2017;43:2025-2033.

Received May 13, 2020 Accepted June 23, 2020 